\title{
Assessment of Environmental Sensitivity to Desertification in Katsina State, Nigeria
}

\author{
G.K. James, I.M. Jega*, A.S. Halilu, O.O. Olojo, A.S. Oyewunmi, J.T. Shar, H. Onuoha, S. Victor, \\ S. Mustapha, I. Shehu, A.N. Waziri, M.M Mahmood, K.S. Salman, A. Isah \\ Hazards and Environmental Management Division, Strategic Space Applications Department, National Space Research and \\ Development Agency (NASRDA) Abuja, FCT, Nigeria
}

Copyright $(\mathrm{O} 2018$ by authors, all rights reserved. Authors agree that this article remains permanently open access under the terms of the Creative Commons Attribution License 4.0 International License

\begin{abstract}
Land degradation and Desertification (LDD) are critical issues facing most states in northern Nigeria, with severe consequences for national food security. Land degradation refers to total loss of the productive capacity of the soils for present and future use while desertification is seen as a process whereby the productivity of arid or semi-arid land falls by $10 \%$ or more. The Environmental Sensitivity to Desertification Index (ESDI) is the most frequently applied indicator-based system for accessing Land Degradation and Desertification. The research reported here adopted the MEDALUS (Mediterranean Desertification and Land Use) approach for identifying environmentally sensitive areas (ESA) to desertification in Katsina State, Nigeria based on Soil Quality Index (SQI), Climate Quality Index (CQI) and Vegetation Quality Index (VQI). The findings from each of these indicators show the variability between the northern and southern parts of Katsina State. The northern part of Katsina state was found to be the most vulnerable area to desertification and is covered by soil having the highest sand depth while the southern part of the state was found to be the least affected by desertification. This result specifically highlights areas in the State that requires urgent attention and remediation. Findings from this research can be used to support informed decision-making and policy development to focus on sustaining the environment, as well as the livelihood of the communities in the affected local government areas in the northern part of the State, given the high sensitivity of the area to desert conditions.
\end{abstract}

Keywords Climate Quality Index, Climate Vegetation Quality Index, Soil Quality Index, Desertification, Environmental Sensitivity, Katsina, Land Degradation, Mediterranean, Policy Desertification

\section{Introduction}

On the 25th of September 2015, world leaders at the
United Nations adopted the 2030 Agenda for Sustainable Development, which includes a set of 17 Sustainable Development Goals (SDGs) and 169 associated targets. These bold, transformative, and universal goals depict the roadmap for the next 15 years [1]. Target 15.3 of the SDGs states as follows: "By 2030, combat desertification, restore degraded land and soil, including land affected by desertification, drought and floods, and strive to achieve a land degradation-neutral world". As a result, Target 15.3 has become a strong vehicle for driving the implementation of United Nations Convention to Combat Desertification (UNCCD), while at the same time contributing to other SDGs, including those relating to climate change mitigation and adaptation, biodiversity conservation, ecosystem restoration, food and water security, disaster risk reduction, and poverty [2]. Land degradation is a major challenge confronting developing countries and this is projected to continue in the long run $[3,4,5,6,7]$. Studies have shown that nearly $80 \%$ of rangeland and dryland forest areas, as well as $30 \%$ of tropical forests and about $50 \%$ of all irrigated cropland in developing countries are classified as degraded [8]. Desertification is the leading land degradation process. According to [9], desertification is defined as "land degradation in arid, semi-arid and dry sub-humid areas resulting from various factors, including climatic variations and human activities". The degree of desertification risk is directly related to certain natural conditions such as climate, topography, natural vegetation, soil, and hydrology, as well as the intensity and type of anthropic activities in the area. In terms of productivity, desertification could be seen as a process whereby the productivity of arid or semi-arid land falls by $10 \%$ or more [10]. Desertification is an advanced stage of land degradation where soil has lost part of its capability to support human communities and ecosystem. Consequently, the direct effect of desertification on land degradation is either the decrease of land productivity or the complete abandonment of agricultural land, which ultimately lead to the food crisis experienced in many arid 
and semi-arid regions, especially Africa. Hence, there is direct relationship between drought, desertification, and food security [11].

In Nigeria, desertification phenomenon has been reported in northern Nigeria since the 1920s, nevertheless, the impact has been more glaring since the famine of 1971 to 1973 in this part of the country. Experts estimate that the Sahara Desert is advancing southwards at the rate of 6.0 percent, every year. Consequently, Nigeria loses about 350,000 hectares of land every year to desert encroachment [12]. This has led to demographic displacements in 11 most affected states in Northern Nigeria: Adamawa, Borno, Bauchi, Gombe, Katsina, Jigawa, Kano, Kebbi, Sokoto, Yobe and Zamfara. The problem is further aggravated because these states are agricultural areas that supply most of the country's agricultural products such as beans, soya beans, tomatoes, melon, pepper, onion and rice. The challenge of desertification is further exacerbated by the fact that the agro-economy of Nigeria is dependent on rainfall and hence affected by fluctuating weather [11]. To date, no published research describes the rate of desertification in Katsina state. Moreover, several efforts have been made at addressing the challenge of desert encroachment in the state, but no significant efforts have been made to assess the efficacy of these efforts. As a result, this study focuses on the assessment of environmental sensitivity to desertification in the state. This is important to planners and intervention agencies as accurate information on which part of the state is severe or otherwise would greatly help in reducing the effects of land degradation and desertification in the state.

\section{Materials and Methods}

\subsection{Study Area}

Katsina state (shown in Figure 1) falls within three agro-ecological zones: The Sahel, the Sudan, and the Northern Guinea Savanna zones [13, 14, 15, 16]. The state was created in 1987 from the defunct Kaduna State and is located between latitude $11^{\circ} 08^{\prime}$ North and $13^{\circ} 22^{\prime}$ North and longitude $6^{\circ} 52^{\prime}$ East and $9^{\circ} 20^{\prime}$ East. It covers a total area of approximately $23,983 \mathrm{~km}^{2}$. Katsina state is made up of 34 local government areas with a population of $5,801,584$ based on the 2006 population census [17] and projected to be $6,740,500$ in 2011. The state is bounded in the East by Kano State, in the West by Zamfara State, in the South by Kaduna State and in the North by the Niger Republic.

Katsina State is located on Nigeria's inselberg landscapes that are generally undulating, characterized by numerous domed hills and occasional flat-topped ridges. General elevation of the area is between $305-610$ meters above sea level [18]. The climate of Katsina State is the tropical wet and dry type (tropical continental climate). Rainfall is between May and September with a peak in
August. The average annual rainfall is about $700 \mathrm{~mm}$ [14]. The pattern of rainfall in the area is highly variable. This can result in severe and widespread droughts that can impose serious socio-economic constraints [19]. Based on the findings of [20], the soil is predominantly ferruginous tropical red and brown soils in the areas underlain by the basement complex rocks.

The general vegetation pattern in the State is Sudan grasslands with dotted shrubs. However, the natural vegetation has been modified over the years due to human activities, including intensive cultivation, bush burning, livestock grazing and browsing. Nevertheless, the northern parts of the State consist of trees that grow long tap roots and thick barks that make it possible for them to withstand the long dry season and bush fires. On the other hand, the southern half of the state belongs to the Northern Guinea Savannah Zone, which consists of broadleaved species with tall tussocky grasses of guinea affinities, mixed up with fine leaved species of thorny trees with continuous short and feathery grass cover [21]. Given the land degradation being experienced in the State, there are afforestation programmes in the state that are focused on the establishment of plantations, woodlots, shelterbelts and trees on farmlands. Some of the planted trees include Azadirachta Indica (Neem), Acadia species and Eucalyptus

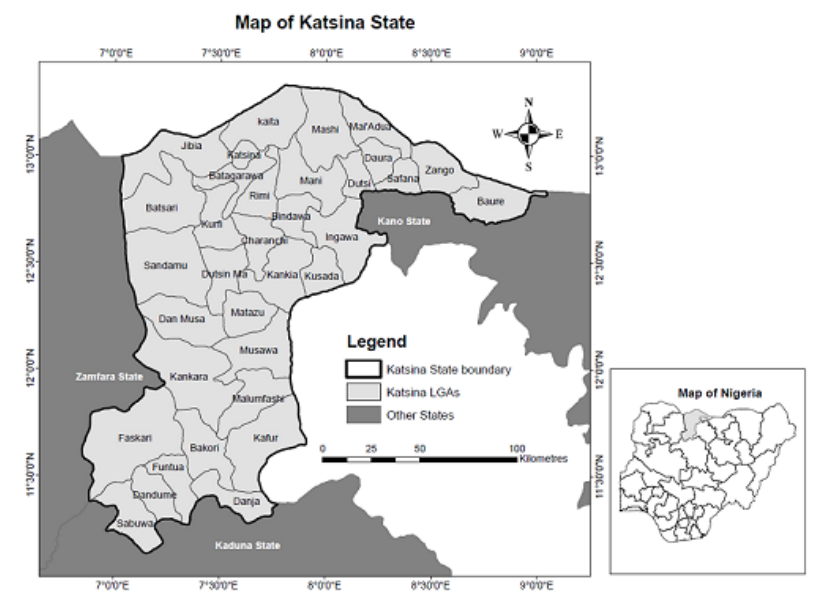

Figure 1. Map of the study Area (Katsina State)

\subsection{Data}

The dataset used for the research, its format and the source are shown in Table 1. However, ancillary datasets were collected from the field to interpret the satellite images acquired for the project. The interpreted images were used as input for Vegetation Quality Index (VQI). Moreover, the field visit provided a better understanding for the interpretation of the environmental sensitivity index.

\subsection{Method}

\subsubsection{Assessment of Environmental Sensitivity to} Desertification

The MEDALUS approach [22] was adopted in this 
study based on the variables that are available in Katsina State. One of the strengths of the MEDALUS approach is that the model can be adapted to available indexes. This implies that the model is scalable subject to the availability of parameters required for the implementation of the various indexes that estimate the environmental sensitivity index. Therefore, the model was adopted for this project given the dearth of data in the public domain on Katsina State. More so, the approach has been adopted in Cabo Verde [23], in Egypt [24]; [25] in Morocco, [26] in Iran [27], and Europe e.g. [28, 29,30,31]

It determines the Environmental Sensitivity to Desertification Index (ESDI) based on the following indicators: Soil Quality Index (SQI), Climate Quality Index (CQI), Vegetation Quality Index (VQI), Water Quality Index (WQI), and Land Management Index (LMI). However, due to the paucity of data for Katsina State in the public domain, this project focused on the following variables: Soil Quality Index (SQI), Climate Quality Index (CQI), and Vegetation Quality Index (VQI); excluding Water Quality Index (WQI) and Land Management Index (LMI). Hence, ESDI was estimated using equation (1) and based on the flow chart presented in figure 2. Using the raster calculator, the resulting thematic map was divided into three segments based on the natural breaks: non-sensitive area, moderate sensitive area, and very sensitive area.

$$
\mathrm{ESDI}=(\mathrm{SQI} * \mathrm{CQI} * \mathrm{VQI}) 1 \backslash 3
$$

Equation (1)

Where:

ESDI: Environmental Sensitivity to Desertification Index SQI: Soil Quality Index

CQI: Climate Quality Index

VQI: Vegetation Quality Index

\subsubsection{Soil Quality Index (SQI)}

The soil constitutes a major component of the earth surface and it supports a large biomass. Hence, when soil is

degraded, it is not able to provide plants with rooting space, water and nutrients; this contributes to land degradation. Two major characteristics of soil were evaluated for Environmental Sensitivity to Desertification: soil water availability and erosion resistance. These qualities are evaluated by using simple soil properties or characteristics such as parent material, texture, soil depth and slope. However, due to the non-availability of dataset for parent material variable in Katsina state, Kosmas et al. [22] formula for evaluating soil quality index was modified (as in Equation 2). Soil depth and texture were obtained from African soil grid data of year 2015 (www.isric.org/content/african-soilgrids-t250m-geotiffs).

Similarly, the slope variable was derived from the Digital Elevation Model (DEM) of Advanced Space borne Thermal Emission and Reflection Radiometer (ASTER) at a spatial resolution of 30 meters. The SQI was computed using equation (2) below:

$(\mathrm{SQI})=(\text { Soil Texture } * \text { Soil Depth } * \text { Slope })^{1 / 3}$ Equation $(2)$

\subsubsection{Climate Quality Index (CQI)}

Climatic Quality Index (CQI) is a combined indicator measured by using parameters that influence water availability to plants, such as aridity, precipitation, and slope [22]. The CQI can be used to assess the climate quality of an area and to evaluate sensitivity to land degradation and desertification [32]. The CQI is calculated as the cube root of aridity index, annual precipitation, and slope of the monitoring area (as in equation (3)).

$$
\mathrm{CQI}=\left(\mathrm{TAP}^{*} \text { aridity index*slope }\right)^{1 / 3} \quad \text { Equation (3) }
$$

Where:

\section{TAP: Total annual precipitation}

The total annual precipitation is a major contributor to the climatic quality index. This is because atmospheric conditions that create shortages of water describe a desert climate, particularly were potential evapotranspiration (ETo) is much greater than precipitation [22]. As a result, the quantity of rainfall and its distribution are the major determinants of biomass production, especially in arid environment. Therefore, decreasing amounts of rainfall combined with high rates of evapotranspiration drastically reduce the soil moisture content available for plant growth and thus contributes to arid conditions [33]. The precipitation database comprises of global annual precipitation in millimeters from 1979 to 2015. The resolution of the datasets is 2.5 degrees. For the purpose of this project, the annual precipitations in millimeters for 2015 of four points were extracted from the global database. These points covered Katsina State. Aridity index is a numerical indicator for average water available in the soil that set climatic conditions in relation to water availability [34]. The term aridity is the ratio between mean annual precipitation (P) and mean annual evapotranspiration (ETo) [35]. An area with high aridity index is more likely to have inconsistent water resources, thereby making it more vulnerable to desertification [22]. Thompson [35] described the following four main causes of regional aridity, cited in [34]: High pressure (e.g. Sahara Desert), Continental winds (Middle East), Rain shadow effect (e.g. northern Rocky Mountains USA) and Cold ocean currents (e.g. coastal Peru). Aridity was evaluated in this study using the ratio of annual precipitation (in millimeters) and annual mean temperature (in degrees Celsius) plus 10, as in equation (4).

$$
\text { Aridity }=(\mathrm{AP} / \mathrm{AMT})+10
$$

Equation (4)

Where:

\section{AP: Annual Precipitation \\ AMT: Annual Mean Temperature}

\subsubsection{Vegetation Quality Index (VQI)}

Vegetation plays a vital role in the ecosystem. It is described as the plant covering an area and it is the most biotic component of the biosphere [36]. 
Table 1. Data Used for the Project

\begin{tabular}{|c|c|c|c|}
\hline Data & Format & Date & Source \\
\hline Soil Grid Data & Raster & $08-02-2015$ & $\begin{array}{c}\text { The International Soil Reference and Information Centre (ISRIC) } \\
\text { (www.isric.org/content/african-soilgrids-t250m-geotiffs) }\end{array}$ \\
\hline Standard Soil Depth & $150 \mathrm{~m}$ Raster & $08-02-2015$ & $\begin{array}{c}\text { The International Soil Reference and Information Centre (ISRIC) } \\
\text { (www.isric.org/content/african-soilgrids-t250m-geotiffs) }\end{array}$ \\
\hline DEM & $30 \mathrm{~m}$ ASTER & $17-10-2011$ & Earth Explorer website (https://earthexplorer.usgs.gov) \\
\hline $\begin{array}{c}\text { Precipitation } \\
\text { Dataset }\end{array}$ & 2.5 degrees & $14-11-2016$ & Version-2 global precipitation climatology project (GPCP) \\
\hline $\begin{array}{c}\text { Annual Mean } \\
\text { Temperature }\end{array}$ & $\begin{array}{c}\text { Degree } \\
\text { Celsius }\end{array}$ & $16-11-2016$ & Giovanni NASA (http://giovanni.gsfc.nasa.gov/giovanni/) \\
\hline $\begin{array}{c}\text { Landsat 8 Satellite } \\
\text { Image }\end{array}$ & Raster & $18-10-2016$ & Earth Explorer (http://earthexplorer.usgs.gov/) \\
\hline $\begin{array}{c}\text { NigeriaSat-1 } \\
\text { Katsina State } \\
\text { Boundary }\end{array}$ & Shapefile & $28-09-2006$ & $\begin{array}{c}\text { Office of the Surveyor General of the Federation (OSGOF) through Second } \\
\text { Administrative Level Boundaries (SALB) dataset project. }\end{array}$ \\
\hline
\end{tabular}

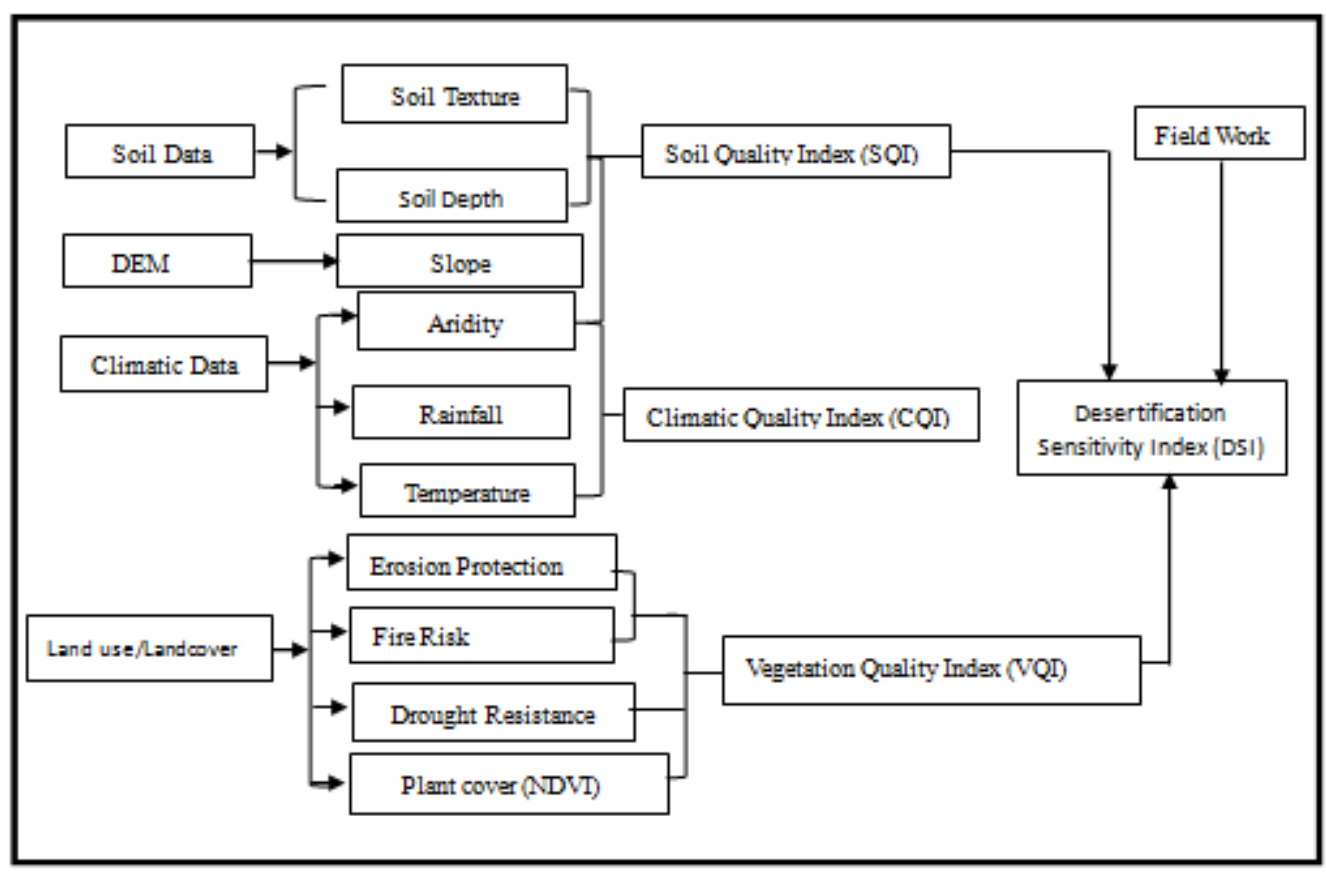

Figure 1. The Flow chart describing the methodology

Vegetation acts as carbon sinks and maintains the water cycle (water supply). Vegetation is a source of food, provides jobs, combats desertification, and performs other ecological functions [37]. The presence of vegetation minimizes the prevalence of desert conditions. The Vegetation Quality Index is evaluated using fire risk, erosion protection, drought resistance and plant cover [22]. Each variable is derived from classified land cover/use classes of the study area. These derivations are based on: the land use class's relative resistance to fire, drought, and soil erosion; and amount of vegetation cover respectively. Weights are thereafter assigned to the land cover classes relative to fire risk, erosion protection, drought resistance and plant cover. Vegetation Quality Index is estimated using equation (5).

$$
\mathrm{VQI}=[\mathrm{FR} * \mathrm{EP} * \mathrm{DR} * \mathrm{VC}]^{1 / 4}
$$

Equation (5)

Where:

\section{FR: Fire Risk}

EP: Erosion Protection

DR: Drought Resistance

VC: Vegetation Cover

Landsat- 8 satellite image covering Katsina state was obtained and projected to UTM Zone 32 North. The satellite image was pre-processed and classified into water bodies, rock outcrop, settlement, vegetation, shrubs/farmlands, and bare surface, using supervised classification approach. Training samples for Katsina state obtained during the field trip to the state as part of this study were used to perform the supervised classification as well as the accuracy assessment. The overall classification accuracy recorded was 86 percent.

Fires, used as a form of land preparation before cultivation in Katsina state, ironically contribute to fire risk in the State. Besides vegetation loss, it distorts the 
properties/nutrients of the soil and leads to loss of biomass. The fire risk map was produced from land use/ land cover classification map developed for this study. The weights that were assigned to the land use/land cover classes were determined based on the vulnerability of the land use/land cover class to fire disturbance [22]. For example, while water body has a very low fire risk, shrubs and vegetation have high fire risk because of their high vulnerability.

Drought has been directly and indirectly related to the climatic conditions of an area. Changes in weather patterns related to climate change observed through overheating of the earth's surface, reduction in rainfall amount and cloud leading to increased evaporation rates are the major drivers of drought [38]. Other human activities also contribute: excessive grazing, improper cropping, and poor soil conservation methods [38]. Therefore, drought resistance determines the ability of a land use/land cover to resist drought. For example, the prevalence of water body and vegetation will reduce the prevalence of drought, hence support very high and high drought resistance, respectively. However, the presence of settlements and bare surface will intensify drought and exhibit low drought resistance. It is also essential to note that the land use/land cover class with high drought resistance will not exacerbate the process of desertification. As a result, since water body has high drought resistance ability, it does not exacerbate the process of desertification, and as a result, it was assigned a low index.

Erosion is significantly one of the sign of land degradation and vegetation and land use are clearly important factors that controls the intensity and the frequency of overland flow and erosion [39, 40]. A land use/land cover class with high erosion protection capability will invariably reduce the susceptibility of an area to desertification process. This was the principle that guided the weight attached to the land use/land cover classes developed for Katsina state. For example, vegetation has high erosion protection capability because of its ability to hold the soil together. The presence of vegetation reduces the susceptibility of an area to desertification process. This parameter is based on the protective role of plant cover against erosion [22]. The Normalized Difference Vegetation Index (NDVI) was used to estimate the plant cover. The amount of plant cover or vegetation cover (VC) in Katsina State was determined from NDVI (equation (6)) derived from Nigeria Sat-X image of Katsina state acquired in 2011. The relationship between NDVI and vegetation cover is presented in equation $6 \mathrm{~b}$ as described by [41].

$\mathrm{NDVI}=\mathrm{NIR}-\mathrm{R} / \mathrm{NIR}+\mathrm{R}$
$\mathrm{VC}=1.333 * 131.877 \mathrm{NDVI}$

Equation (6a)

Equation (6b)

\section{Results}

\subsection{Vegetation Quality Index (VQI)}

The parameters for the Vegetation Quality Index (VQI); fire risks index, drought resistance, erosion protection and plant cover (derived from land use/ land cover map for Katsina State) were combined and their results are shown in table 2. The northern parts of Katsina State have high and very high fire risk conditions. The southern segment is prone to high fire risk conditions with patches of low fire risk conditions in the mountainous segments of the state. As a result, 89 percent of the total land area of the State is at high and very high risk in terms of susceptibility to the combined parameters (see table 2).

Table 2. Vegetation Quality Index Parameters

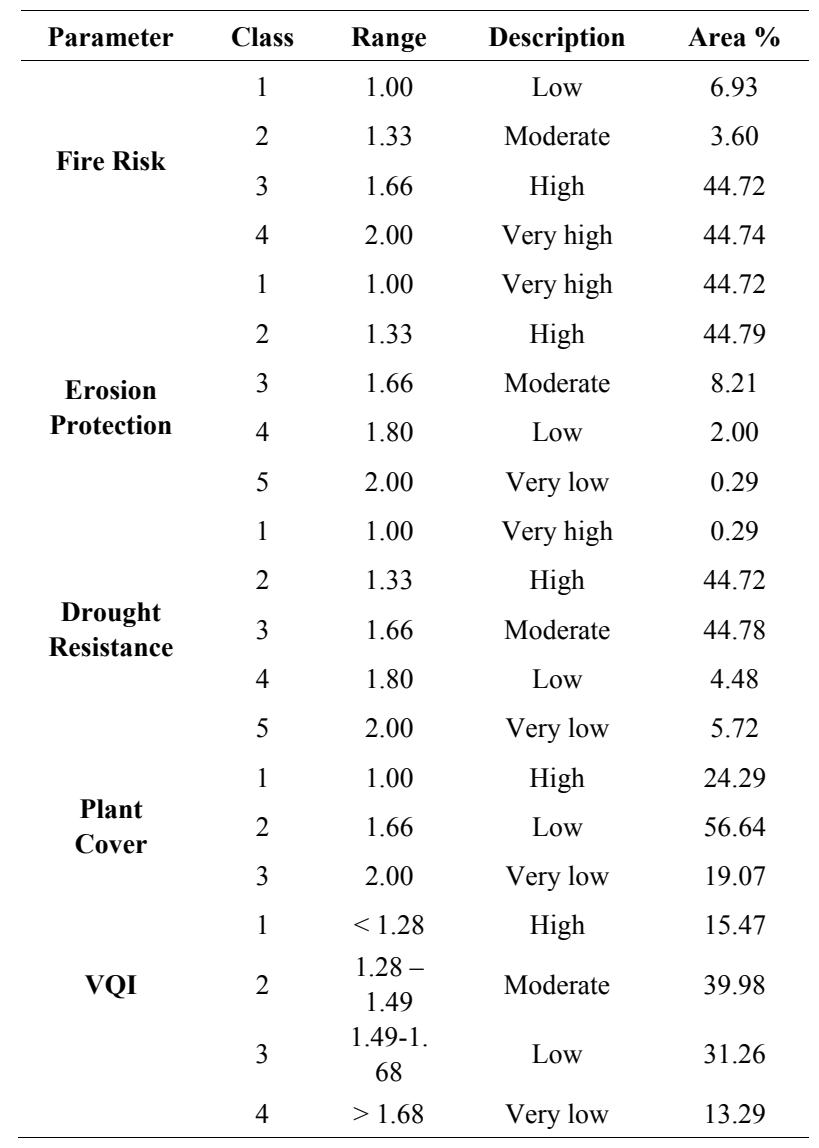

The Vegetation Quality Index (VQI) results showed that $44 \%$ of the study areas have low/very low vegetation quality (see table 2). Approximately 40 percent of the land area covered in the state has moderate vegetation quality and $15 \%$ of the land area is covered by high vegetation quality. The results are generally based on the land use/cover of Katsina state with the assumption that other factors are held constant. Such factors include climate, rainfall, soil quality and other socioeconomic parameters [42].

The low/very low vegetation quality is mainly in the northern part of the State. The local government areas within these categories includes Kaita, Zango, Mai'Adua, Mashi and Daura. The low vegetation quality in this area can be attributed to the climatic conditions: low rainfall, high temperature, and the soil characteristics of the area [43]. 
The soils are generally sandy and prone to wind and water erosion leading to poor quality for vegetation growth. In addition to these two factors, there is great human dependence on the vegetation in this region for fuel wood grazing and farming. The vegetation quality of the northern area of the State makes it highly prone to land degradation from erosion and culminating in desertification. The areas with mostly moderate vegetation quality known as a transitional zone, consists of local government areas such Dan Musa, Dutsin Ma and Matazu. These areas have moderate vegetation quality due to moderate amount of rainfall and average temperature of the area [44]. Also, the area has a mixture of sandy and loamy soils which is favorable for cultivation; hence the presence of farmlands in the area.

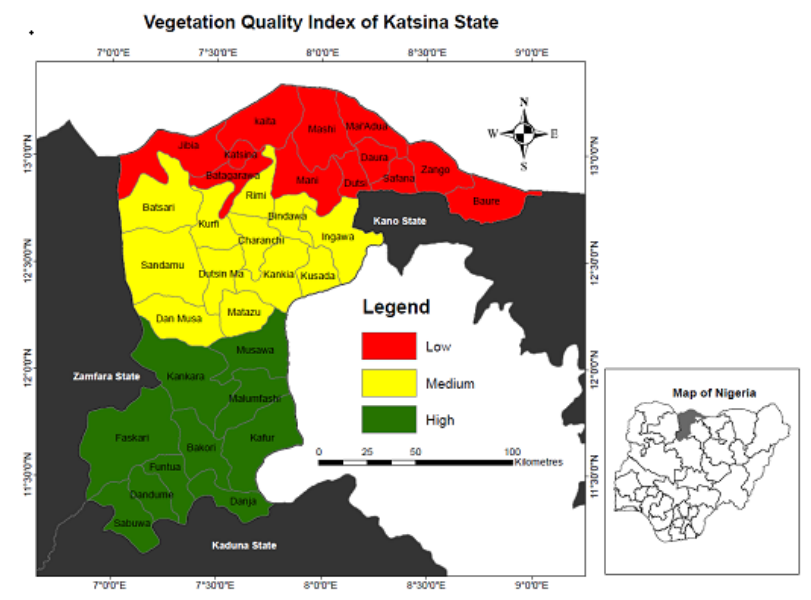

Figure 2. Vegetation Quality Index map of Katsina State

The southern part of the state has mainly high vegetation quality. Local government areas in this vegetation quality class include Kankara, Danja, Sabuwa and Funtua. The vegetation quality index map of the state show that this area is highly vegetated (figure 3 ). This area is made of mainly clay loamy soils with low temperatures of $<260$ c annual average in 2015 and high rainfall of $>870 \mathrm{~mm}$ annual average in 2015 . The area contains most forest trees in the State. The presence of thick vegetation in this area makes it less prone to soil erosion and desertification.

\subsection{Climate Quality Index}

The degree of the CQI indicates the susceptibility of an area to desertification based on climatic factors alone. As a result, areas with very high CQI are more likely to support vegetation growth and would not create, nor support desert conditions, when all other factors are held constant. Conversely, areas with poor CQI will exacerbate the prevalence of desert conditions. Moreover, such areas have reduction in rainfall and high temperatures.

These have adverse impact on ecosystems in several ways; longer drying season, diseases like meningitis and measles, heat wave, variation in the hydrological cycles, energy sector, industrial sector, tourism, soil degradation, forest fire, loss of biodiversity as well as negative impact on habitat. Agricultural activities are also adversely affected by poor CQI which is one of the major occupations in these areas. The climatic data analyzed to obtain the CQI clearly shows that the Northern part of Katsina State has the highest temperature and least rainfall when compared with the other parts of the State. It also shows a decrease in temperature and an increase in the amount of rainfall from North to South. In Nigeria, an increasing temperature, and a reduction in the amount of rainfall is seen as an evidence of climate change [45]. The VQI shows that the southern part of the state has higher vegetation quality than the northern part. (see figure 4)

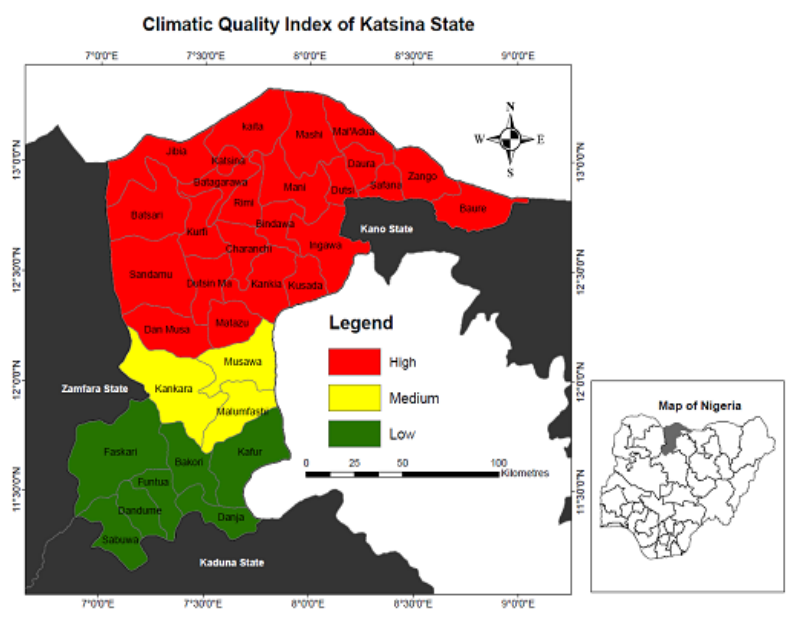

Figure 4. Climate Quality Index map of Katsina State

There is dense vegetation in the southern part of the state with very good vegetation health. The northern part of the state has sparse vegetation. One of the reasons attributed to this change in climatic conditions is the Intertropical Convergence Zone (ITCZ) which is continually shifting between the South and the North. These shifts modify the climatic conditions of different ITCZ within Nigeria [46]

\subsection{Soil Quality Index Result}

The soil quality index was generated using the parameters of slope, soil depth and soil texture. The state is dominated by gentle slope on average. However, the mountainous regions of the state, for example, the mountains in Safana local government area, are characterized by steep slopes. The soil depths vary from the northern segment of the state to the southern segments. While the northern parts of the state, for example, Dagon Dawa, Dumbessa, Baure, and Balsari communities, exhibit deep sandy soil, the southern parts such as Funtua and Danja local government areas, are characterized by shallow soil. The soil texture is characterized by $66 \%$ of sandy soil. This is characterized with sand particles; coarse texture and the soil is made up of deep sandy soil. This soil horizon has low water holding capacity, as a result, the soil cannot 
provide enough water to plant roots for growth. Therefore, the soil is dry and devoid of substantial plant growth. However, there are patches of high-quality soil spread in different sections of the State; particularly in the southern part of the state. The Soil Quality Index shows that soil types and quality differ in each zone. (see figure 5) The northern part of the state is sandy while the southern part has very rich loamy soil. All these factors combine to give the different desertification impacts in different parts of Katsina state. The interplay of low rainfall, high temperature and a land mass predominantly covered by sandy soil has made the northern region the most susceptible to desertification. These environmental conditions have limited the livelihood options of the people in the region to rain fed agriculture and herding. This has resulted in over grazing from livestock and increase in agricultural activities; culminating in the change of land use and the alteration of the land surface albedo.

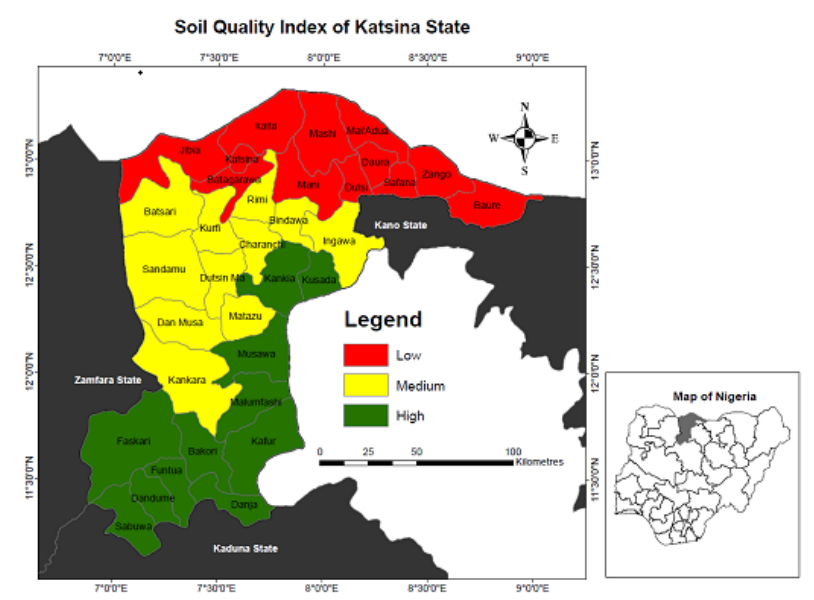

Figure 5. Soil Quality Index map of Katsina State

This is believed to be contributing further to change in the region's climate (particularly, precipitation) [47]. Furthermore, the poor management of water resources have contributed to the exacerbation of desert conditions in the area. These factors have contributed to the inability of the region to promptly recover from extreme drought events.

\subsection{Results and Analysis of Environmental Sensitivity to Desertification Index}

The result of the Environmental Sensitivity to Desertification Index (ESDI) is presented in Table 3. The table shows areas (in hectares) covered by each sensitivity index and the relative percentages of the coverage. The thematic map showing the three categories of environmental sensitivity to desertification index (i.e. non-sensitive area, moderate sensitive area, and very sensitive area) is presented in figure 6 .

The very sensitive area, which is prevalent in the Northern part of Katsina State (figure 6), is the most vulnerable area to desertification. This area has a sensitivity index greater than 1.8 and covers an area of 917,873 hectares, that is, over $38 \%$ of the total land area of Katsina State (see Table 3)

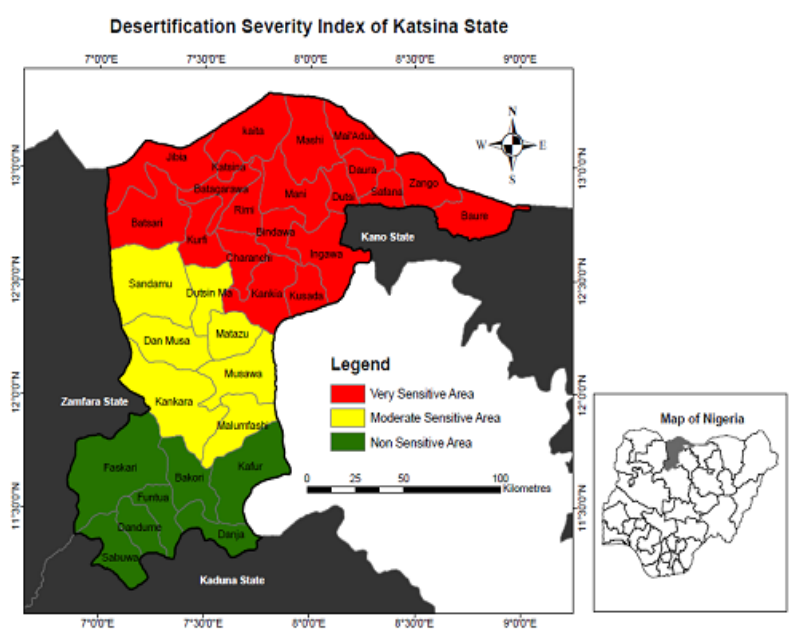

Figure 6. Desertification Severity Index

Table 3. Environmental sensitivity to desertification index with affected areas and their relative percentages

\begin{tabular}{cccc}
\hline ESDI & Description & Area (ha) & $(\%)$ \\
\hline$<1.2$ & Non-sensitive area & $663,628.05$ & 27.70 \\
$1.2-1.8$ & Moderate sensitive area & $814,291.57$ & 33.99 \\
$>1.8$ & Very sensitive area & $917,872.74$ & 38.31 \\
Total & & $2,395,792.36$ & 100 \\
\hline
\end{tabular}

During the field trip to Katsina state (a major component of this study), it was observed that the Northern part of Katsina State is covered by soil having the highest sand depth (this is shown in figure 7). This is not surprising because the region falls within the Sahel zone and research has shown that the soil in the Sahel zone is generally sandy and of low fertility [48].

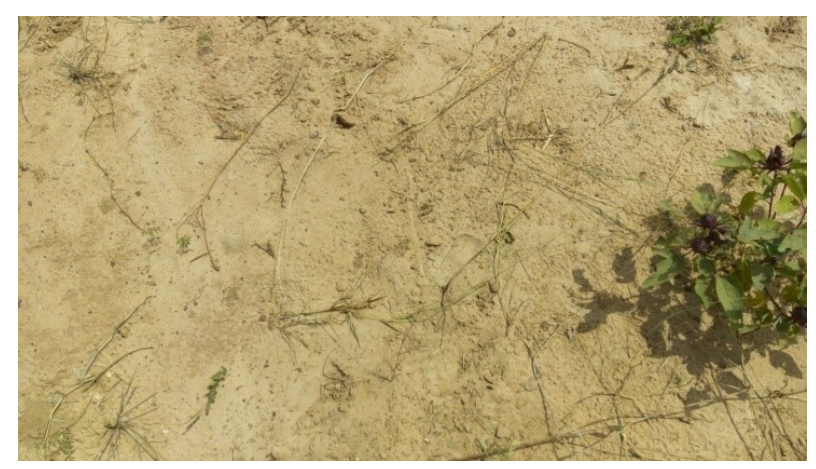

Figure 7. andy soil in Mai'Adua

In addition, the area has patches of brush, grasses, and stunted trees as shown in figure 8 . The very sensitive area covers 20 local government areas of Katsina State, including the frontline local government areas sharing boundary with Niger Republic. The local government areas are; Katsina, Kurfi, Kankia, Batagarawa, Kusada, 
Charanchi, Jibia, Batsari, Mai'Adua, Mashi, Kaita, Mani, Dutsi, Daura, Sandamu, Zango, Baure, Ingawa, Bindawa, and Rimi local government areas. The moderate sensitive area (see Figure 6) has a sensitivity index of between 1.2 and 1.8. It covers an area of $814,291.57$ hectares, that is, about $34 \%$ of the total land area of Katsina State (see table $3)$.

This area can be referred to as a transition area because it has a mixture of the characteristics of both the very sensitive and non-sensitive indices. The mixture of classes in the moderate sensitive area could be the reason why mixed cropping is practiced in this region. The local government areas classified as moderate sensitive areas are; Dutsin-ma, Safana, Dan Musa, Matazu, Kankara, Malumfashi and Musawa.

The Southern part of the state is the least affected by desertification conditions and is referred to as the non-sensitive area. The non-sensitive area (as shown in figure 6) has a sensitivity index of less than 1.2 and covers an area of $663,628.05$ hectares, about $28 \%$ of the total land area of Katsina State (see table 3). This southern part is made up of the following local governments such as: Danja, Bakori, Funtua, Faskari, Sabuwa Kafur and Dandume. Sugarcane, rice and yam are mostly planted in this area. The area is more vegetated (figure 9) compared with the other parts of the state.

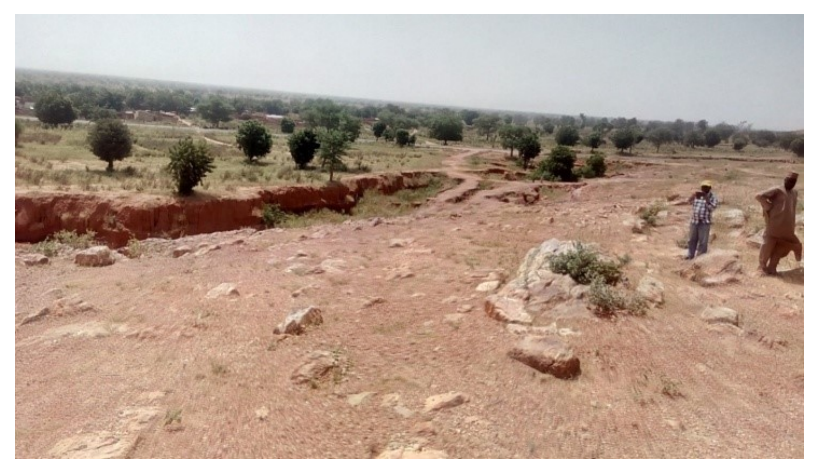

Figure 8. The sparse vegetation in Baure

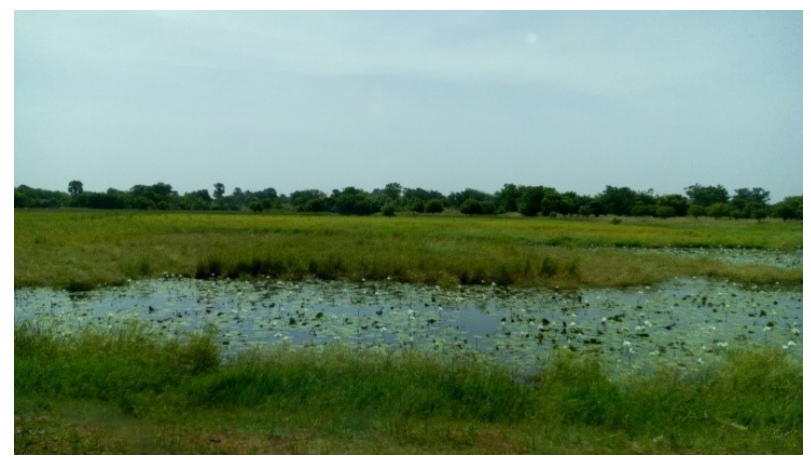

Figure 9. Vegetated area in Funtua

The non-sensitive area has the smallest land mass. This means that about $72 \%$ of the total land area of Katsina state is under the threat of desertification. The variation in the sensitive areas to desertification within the state as clearly shown in the ESDI is as a result of the following factors: agro-ecological zones, the interaction and interplay of climate, soil types, and vegetation. Katsina state cuts across three agro-ecological zones: Sahel, Sudan and the Northern Guinea Savanna zones [13]. Each of these zones is characterized by distinct climate factors, vegetation, and soil properties. The Northern part of Katsina falls into the Sahel Zone, the Central falls within the Sudan while the Southern part falls within the Northern Guinea Savannah Zone [13].

\section{Conclusions}

Land degradation and Desertification (LDD) are critical issues facing most states in northern Nigeria, with severe consequences for national food security. Land degradation refers to the deterioration or total loss of the productive capacity of the soils for present and future use [49]. Desertification is the outcome from surface land degradation [50]. The consequences of land degradation and desertification include: conflicts between farmers and herdsmen; reduced production capacity (food security), poverty and inconsistency in implementing policies. The Environmental Sensitivity to Desertification Index (ESDI) is the most frequently applied indicator-based system for accessing Land Degradation and Desertification. The study reported here adopted the MEDALUS (Mediterranean Desertification and Land Use) approach for identifying environmentally sensitive areas (ESA) to desertification in Katsina State, Nigeria. Three indicators were used to estimate ESDI for Katsina State. These indicators include Soil Quality Index (SQI), Climatic Quality Index (CQI), and Vegetation Quality Index (VQI). The findings from each of these indicators show the variability between the northern and southern segments of Katsina State. The implications of the findings in this study are many. First, the northern part of Katsina State is highly vulnerable to desertification process. The local government areas affected include: Katsina, Kurfi, Kankia, Batagarawa, Kusada, Charanchi, Jibia, Batsari, Mai-adua, Mashi, Kaita, Mani, Dutsi, Daura, Sandamu, Zango, Baure, Ingawa, Bindawa, and Rimi local. The livelihood of the communities in these local government areas have been large limited. As a result, there is constant migration down to southern Katsina and southern Nigeria. This migration is responsible for the clash between the herdsmen and farmers with the loss of lives and properties. Furthermore, this migration will drive the change in land use/land cover in areas inhabited by the migrants. Second, there is a transition zone in the State (i.e. moderate sensitive area). This zone exhibits a mixture of the characteristics of the very sensitive (northern part of Katsina State) and the non-sensitive (southern part of Katsina State). The local government areas that are within the moderate sensitive areas are Dutsin-ma, Safana, Dan Musa, Matazu, Kankara, 
Malumfashi and Musawa. Third, the southern part of the State is non-sensitive to desert conditions. The local government areas that make up the non-sensitive group include: Danja, Bakori, Funtua, Faskari, Sabuwa Kafur and Dandume. This area receives more rainfall than the northern parts and thus has more vegetal cover. This climatic and ecological advantage makes the area less vulnerable to desert conditions compared to the northern part.

\section{Recommendation}

Based on the findings of this study (i.e. the ESDI varies from North to South, with a transition zone), there are several recommendations that will ensure a sustainable Katsina state environment. Over time, the distinction of ESDI in the state may vary due to further land degradation if adequate measures are not taken to control and mitigate the sensitivity of the state to desert conditions. A first recommendation therefore is the need to effectively enforce existing environmental laws. One of such environmental laws is the prohibition of the unsustainable logging for fuel wood. It was discovered during the field visit to Katsina state by this research team that Niger and Nigeria have similar laws on the prohibition of unsustainable logging practices. While the law is strictly enforced in Niger, with resultant existence of many shrubs in the country, the story is different for Nigeria. The lack of adequate enforcement on the Nigerian side means that communities on the Niger side of the border cross into the Nigerian side and harvest fuel wood.

A second recommendation is to focus intervention in the northern part of the State given the high sensitivity of the area to desert conditions. The focus should be on sustaining the environment as well as the livelihood of the communities in the local government areas. Given that the predominant source of livelihood is rain fed agriculture and herding, drought resistant seedlings as well as organic manure should be given to the farmers for the planting seasons. In addition, boreholes should be provided with provision for solar driven pumping machine to pump the water from the borehole. Ranching should be encouraged for the herders. This is economical and can support the production of the much-needed organic manure required by the farmers. Finally, another study should be commissioned to carry out the desertification severity assessment in the northern part of the State. The current study has only highlighted areas in the State that requires urgent attention and remediation.

\section{REFERENCES}

[1] SDKP 2017. Sustainable Development Knowledge
Platform.

URL:https://sustainabledevelopment.un.org/topics/sustaina bledevelopmentgoals

[2] The Global Mechanism of the UNCCD 2016. Land Degradation Neutrality:The Target Setting Programme. ISBN 978-92-95110-07-6- (e-copy).

[3] Chisholm A, Dumsday R. Land Degradation-Problems and Policies. Cambridge: Cambridge University Press; 1987.

[4] Eckholm EP. Losing Ground: Environmental Stress and World Food Prospects. New York: Norton \& Company, Incorporated, W. W.; 1976.

[5] Ward A. Progress for a Small Planet. New York: W.W. Norton; 1979.

[6] Barbier EB, Burgess JC. Agricultural Pricing and Environmental Degradation, Working Paper Series, W.P.S. 960, Prepared as Background Paper for World Development Report 1992.

[7] Pimentel D, Harvey C, Resosudarmo P, Sinclair K, Kurz D, McNair M, et al. Environmental and economic costs of soil erosion and conservation benefits. Science, New Series 1995;267(5201):1117-1123.

[8] Leonard HJ, Yadelman M, Stryker JD, Browder JO, DeBoer AJ. Environment and the poor: Development strategies for a common agenda. New Brunswick.: Transaction Books; 1989.

[9] The United Nations Convention to Combat Desertification (UNCCD) 2004: "A carrying pillar in the global combat against land degradation and food insecurity". Background paper for the San Rossore meeting 'Climate change: a new global vision. Pisa, Italy, 15-16 July 2004.

[10] Miller GT. Environment Science: Working with Earth. New York: Wadsworth Publishing Company; 1999.

[11] Olagunju TE. Drought, desertification and the Nigerian environment: A review. Journal of Ecology and Natural Environment 2015;7(7):196-209.

[12] Tercula I. Desertification: Water Scarcity hits Sokoto Farmers. 2015.

[13] Ogungbile AO, Tabo R, Duivenbooden NV. Multiscale characterization of production systems to prioritize research and development in the Sudan Savannah Zone of Nigeria. 1999. Abaje IB. Introduction to soils and vegetation. Kafanchan: Personal Touch Productions; 2007.

[14] Abaje IB. Introduction to soils and vegetation. Kafanchan: Personal Touch Productions; 2007.

[15] Abaje, I. B., Sawa, B. A. and Ati, O. F. Climate Variability and Change, Impacts and Adaptation Strategies in Dutsin-Ma Local Government Area of Katsina State, Nigeria. Journal of Geography and Geology 2014;6(2):103-112.

[16] Tukur R, Adamu GK, Abdulrahid I, Rabi'u M. Indigenous trees inventory and their multipurpose uses in Dutsin-Ma area, Katsina State. European Scientific Journal 2013;9(11):288-300

[17] National Population Census, NPOPC (2016). population by state and sex. 
Url: /http://www.population.gov.ng/files/nationafinal.pdf. Assessed: $15^{\text {th }}$ March 2016.

[18] Ibrahim, Y.E. 2005, An Overview on 'The Concept of Biodiversity and Its Relationship to Human Activities, Ph.D. Term Paper edn, Bayero University Kano, Kano, Nigeria.

[19] Abaje, I.B., Ati, O.F. \& Iguisi, E.O. 2012, "Recent Trends and Fluctuations of Annual Rainfall in the Sudano-Sahelian Ecological Zone of Nigeria: Risks and Opportunities.", Journal of Sustainable Society, vol. 1, no. 2, pp. 44-51.

[20] Ibrahim, Y.E., Nuraddeen, A.M. \& Abubakar, A.R. 2014, "Factors Affecting Soil Quality Maintenance In Northern Katsina State, Nigeria. ", Science World Journal, vol. 9, no. 4, pp. 39-46.

[21] Ladan Suleiman Iguda 2014. Achieving Effective Vegetation Cover in Katsina Urban Area, Katsina State Nigeria. Global Journal of Science Frontier Research: Environment \& Earth Science, Volume 14 Issue 3

[22] Kosmas C, Kirkby M, Geeson N editors. The Medalus project Mediterranean desertification and land use,Manual on key indicators of desertification and mapping environmentally sensitive areas to desertification. European environment and climate research program - Theme: Land resources and the threat of desertification and soil erosion in Europe. Europe: European Commission; 1999.

[23] Tavares, J.D.P., Baptista, I., Ferreira, A.J.D., Amiotte-Suchet, P., Coelho, C., Gomes, S., Amoros, R., Reis, E.A.D., Mendes, A.F., Costa, L., Bentub, J. \& Varela, L. 2015, "Assessment and mapping the sensitive areas to desertification in an insular Sahelian mountain region Case study of the Ribeira Seca Watershed, Santiago Island, Cabo Verde. ", Catena, vol. 128, pp. 214-223.

[24] Ali, R.R. \& ElBaroudy, A.A. 2008, "Use of GIS in mapping the environmental sensitivity to desertification in Wadi El Natrun Depression, Egypt.", Australian Journal of Basic and Applied Sciences, vol. 2, no. 1, pp. 157-164.

[25] Gad, A. \& Lotfy, I. 2008, "Use of remote sensing and GIS in mapping the environmental sensitivity areas for desertification of Egyptian territory", eEarth Discussions, vol. 3 , pp. 41-85.

[26] Bouabid, R., Rouchdi, M., Badraoui, M., Diab, A. \& Louafi, S. 2010, Land Degradation and Desertification: Assessment, Mitigation and Remediation, pp. 131-145.

[27] Honardoust, F., Ownegh, M. \& Sheikh, V. 2011, "Assessing desertification sensitivity in the northern part of Gorgan Plain, southeast of the Caspian Sea, Iran.", Research Journal of Environmental Sciences, vol. 5, no. 3, pp. 205-220.

[28] Basso, F., Bove, E., Dumontet, S., Ferrara, A., Pisante, M., Quaranta, G. \& Taberner, M. 2000, "Evaluating environmental sensitivity at the basin scale through the use of geographic information systems and remotely sensed data: an example covering the Agri basin - Southern Italy.", Catena, vol. 40, no. 1, pp. 19-35.

[29] Salvati, L. \& Zitti, M. 2009, "Assessing the impact of ecological and economic factors on land degradation vulnerability through multiway analysis, Ecological Indicators, vol. 9, no. 2, pp. 357-363.
[30] Contador, J.F.L., Schnabel, S., Gutiérrez, A.G. \& Fernández, M.P. 2009, "Mapping sensitivity to land degradation in Extremadura. SW Spain", Land Degradation \& Development, vol. 20, no. 2, pp. 129-144.

[31] Santini, M., Caccamo, G., Laurenti, A., Noce, S. \& Valentini, R. 2010, "A multi-component GIS framework for desertification risk assessment by an integrated index.", Applied Geography, vol. 30, pp. 394-415.

[32] Ferrara A, Bellotti A, Faretta S, Mancino G, Taberner M. Identification and Assessment of Environmentally Sensitive Areas by Remote Sensing. MEDALUS III 2.6.2. OU Final Report. 1999.

[33] Kosmas C, Danalatos N, Moustakas N, Tsatiris B, Kallianou C, Yassoglou N. The impacts of parent material and landscape position on drought and biomass production of wheat under semi-arid conditions. Soil Technology 1993; $6: 337-349$.

[34] Maliva R, Missimer T. Arid Lands Water Evaluation and Management. Verlag Berlin Heidelberg: Springer; 2012.

[35] Thompson RD. The climatology of arid world. University of Reading, UK, Department of Geography 1975; Paper No. $35: 39$

[36] Science Daily, 2014. Definition of Vegetation. https:/www.sciencedaily.com/terms/vegetation.htm [assessed 4th December 2016].

[37] United Nations Environmental Programme (UNEP) (2011) - World Environment Day - Forests: Nature at your service 05 June.URL: http://www.une p.org/wed/theme. (Assessed 2/05/2017)

[38] United Nations Economic Commission for Africa (UNECA). Africa Review Report on Drought and Desertification (Main Report) July 2007. http://www.sarpn.org/documents/d0002805/Report on dr ought_UNECA_Aug2007.pdf? (Assessed on 8/05/2017)

[39] Bryan RB, Campbell IA. Runoff and sediment discharge in a semi-arid Ephemeral drainage basin, Zeit. Geomorphology 1986; 58:121-143.

[40] Mitchell DJ editor. The use of vegetation and land use parameters in modelling catchment sediment yields. Chichester: J. Wiley \& Sons; 1990.

[41] Zhang X, Drake NA, Wainwright J, Mulligan M. Comparison of slope estimates from low resolution DEMs: scaling issues and a fractal method for their solution. Earth Surface Processes and Land forms, 1999;24:763-779.

[42] Prăvălie R, Săvulescu I, Patriche C, Dumitraşcu M, Bandoc G. Spatial assessment of land degradation sensitive areas in southwestern Romania using modified MEDALUS method. Catena 2017; 153:114-130.

[43] Herrmann SM, Anyamba A, Compton J, Tucker C. Recent trends in vegetation dynamics in the African Sahel and their relationship to climate. Global Environmental Change 2005; 15:394-404. (NOAA 2017

[44] National Oceanic and Atmospheric Administration. National Center for Environmental Information. URL: https://www.ncdc.noaa.gov/sotc/global/201713 
[45] Odjugo PO. Quantifying the Cost of Climate Change Impact in Nigeria: Emphasis on Wind and Rainstorms. Journal of Human Ecology 2009;28(2):93-101.

[46] Udo IA, Okujagu CU. Assessment of Inter-Tropical Convergence Zone (ITCZ) Impact on Precipitation in Six Locations in Nigeria. International Journal of Science and Research (IJSR) 2014;3(3):2736-2739.

[47] Smith V. The Sahel Region: CE397 - Transboundary Water Resources. 2008.
[48] Ayanwal AB, Adekunle AA. The influence of information and communication technology on farm income in Katsina state of Nigeria. Ghana Journal of Development Studies 2006;3(1):16-34.

[49] Food and Agriculture Organization. The State of Food and Agriculture. World Food Security, World Fisheries and the Law of the Sea. URL: http://www.fao.org/3/a-ap660e.pdf.

[50] Zheng SL, Luo P, Wang X, Li H, Lin P. Desertification in Western Hainan Island, China (1959 to 2003). Land Degradation and Development 2007; 18:473-485. 